ISSN 1442-3707

Prediction of Monthly Discharge in Ungauged Catchments Under Agricultural Land Use in the Upper Ping Basin, Northern Thailand.

Schreider, S.Yu., Jakeman, A.J., Gallant, J. and Merritt, W.S.

iCAM Working Paper 2000/02 



\section{INTEGRATED WATER RESOURCES ASSESSMENT AND MANAGEMENT (IWRAM) FRAMEWORK PROJECT}

\section{BACKGROUND}

Due to mounting and conflicting human pressures, stakeholders in northern Thailand are facing a crucial policy problem typical of many regions in Asia, namely how to plan for the sustainable and rational use, protection, conservation and management of land and water resources.

\section{Project objectives and output}

This project focuses on assessment of upland agricultural systems. It uses an international, inter-disciplinary team approach to develop decision support tools that will assist the Royal Project Foundation, government and other stakeholders to identify and assess the implications of a series of 'what if' scenarios.

The framework aims to be sufficiently generic and portable to be applicable in other agricultural, agro-forestry and aquaculture resource management environments.

\section{The Research Partnership}

The IWRAM project is a collaboration between a number of Thai and Australian agencies: Royal Project Foundation of Thailand; Australian Centre for International Agricultural Research; Department of Land Development; Office of Highland Development, Australian National University; Royal Forestry Department; University departments from Chiang Mai, Maejo and Kasetsart.

The first phase of the project focuses on the Mae Chaem river basin, a 4,000 $\mathrm{km}^{2}$ subsidiary of the Ping River in northern Thailand. It commenced in late 1997 and will be completed in late 2000.

\section{THE RESEARCH PARADIGM}

Multi-disciplinary analysis - the disciplines used in this integrated analysis include economics; hydrology; anthropology; social psychology and crop science.

Modelling - Scenarios are 'what if' tools developed to explore likely trends in resource use. Scenarios may be developed around agricultural or conservation policies, demographic change, potential climate variability, or changes on the world market for exported goods. Input from a range of stakeholders are being obtained to define scenarios that reflect current decision making processes. The decision support tools are being designed to portray effects of the various scenarios on multiple indicators and the trade-offs between them.

The way in which scenarios apply the decision support tools is through an integrated modelling approach. Hydrological modelling of sub-catchment processes is being combined with models of household decision making. Households are being grouped into "Resource Management Unit" (RMU) types based on similarities in biophysical, economic and sociocultural attributes. The RMU situates the socially and economically constituted agricultural household in its biophysical environment. One of the aims is to examine the way in which different RMU types respond to scenario conditions and the implications of upstream decision making on other households in the catchment. A Decision Support System will integrate the models and link them to a geographical information system (GIS).

\section{Case Studies}

Five sub-catchments with varying patterns of resource management and use are being used as case study areas for developing and trailing the decision support tools. The case-studies, selected by and involving local resource managers, reflect different biophysical, cultural and policy drivers of change. They will develop and assess alternative scenarios for addressing the issues present in these sub-catchments. Case study issues include upstream/downstream water conflict; access to forest resources; agricultural intensification and extension and soil degradation. 


\begin{tabular}{|c|c|}
\hline \multicolumn{2}{|c|}{ PROJECT PERSONNEL - INSTITUTIONS } \\
\hline THE AUSTRALIAN TEAM & THE THAILAND TEAM \\
\hline $\begin{array}{l}\text { Professor Tony Jakeman } \\
\text { Overall Project Leader and Biophysical Component Leader, } \\
\text { CRES/iCAM } \\
\text { The Australian National University } \\
\text { Phone: } 61 \text { (2) } 62494742 \\
\text { Fax: } 61 \text { (2) } 62798395 \\
\text { Email: tony @ cres.anu.edu.au }\end{array}$ & $\begin{array}{l}\text { Santhad Rojanasoonthon } \\
\text { Overall Project Leader } \\
\text { Royal Project Foundation } \\
\text { Chiang Mai Thailand } \\
\text { Phone: } 66 \text { (53) } 890098 \\
\text { Fax: } 66 \text { (53) } 267894 \\
\text { Email: santhr@mozart.inet.co.th }\end{array}$ \\
\hline $\begin{array}{l}\text { Chris Buller } \\
\text { Project Manager } \\
\text { Phone: } 61 \text { (2) 6249 } 3568 \\
\text { Email: buller@cres.anu.edu.au }\end{array}$ & $\begin{array}{l}\text { Nootsuporn Krisdatarn - Project Manager and } \\
\text { Socio-cultural Component Researcher } \\
\text { Royal Project Foundation } \\
\text { Chiang Mai Thailand } \\
\text { Phone: } 66 \text { (53) } 890098 \\
\text { Email: nootsuporn@ @ chiangmai.a-net.net.th }\end{array}$ \\
\hline $\begin{array}{l}\text { Dr Helen Ross } \\
\text { Socio-cultural Component Leader } \\
\text { Phone: } 61 \text { (2) } 62492159 \\
\text { Email: hross@cres.anu.edu.au }\end{array}$ & $\begin{array}{l}\text { Bandith Tansiri } \\
\text { Primary DSS stakeholder-phase I } \\
\text { Department of Land Development } \\
\text { Bangkok Thailand } \\
\text { Phone: } 66 \text { (2) } 5797589\end{array}$ \\
\hline $\begin{array}{l}\text { Michelle Scoccimarro } \\
\text { Economics Component Leader } \\
\text { Phone: } 61 \text { (2) 6249 } 5013 \\
\text { Email: michelle@cres.anu.edu.au } \\
\end{array}$ & $\begin{array}{l}\text { Dr Penporn Janekarnkij } \\
\text { Economics Component Co-leader } \\
\text { Phone: } 66 \text { (2) } 5613467 \text { ext } 114 \\
\text { Email: fecoppj@ nontri.ku.ac. } \\
\end{array}$ \\
\hline $\begin{array}{l}\text { Dr Andrew Walker } \\
\text { Socio-cultural and Economic Component Researcher } \\
\text { Phone: } 61 \text { (2) } 62494568 \\
\text { Fax: } 61 \text { (2) } 62492055 \\
\text { Email: ajwalker@cres.anu.edu.au }\end{array}$ & $\begin{array}{l}\text { Dr Varaporn Punyawadee } \\
\text { Economic Component Co-leader } \\
\text { Phone: } 66 \text { (53) } 498154 \\
\text { Email: nong@maejo.mju.ac.th }\end{array}$ \\
\hline $\begin{array}{l}\text { Dr Claude Dietrich } \\
\text { Decision Support Component Researcher } \\
\text { Phone: } 61 \text { (2) } 62495018 \\
\text { Email: claude@cres.anu.edu.au }\end{array}$ & $\begin{array}{l}\text { Karn Trisophon } \\
\text { Decision Support Component Leader } \\
\text { Phone: 66 (53) } 890098 \\
\text { Email: hric@ chmai.loxinfo.co.th }\end{array}$ \\
\hline $\begin{array}{l}\text { Dr Sergei Schreider } \\
\text { Biophysical Component Researcher } \\
\text { Phone: } 61 \text { (2) } 62493381 \\
\text { Email: sergei@cres.anu.edu.au }\end{array}$ & $\begin{array}{l}\text { Dr Somporn Sangawongse } \\
\text { Decision Support Component Researcher } \\
\text { Phone: } 66 \text { (53) } 943527 \\
\text { Email: somporn@chiangmai.ac.th }\end{array}$ \\
\hline $\begin{array}{l}\text { Dr Pascal Perez } \\
\text { Biophysical Component Researcher } \\
\text { iCAM/CRES } \\
\text { Phone: } 61 \text { (2) } 62490652 \\
\text { Email: perez@ cres.anu.edu.au }\end{array}$ & $\begin{array}{l}\text { Dr Chapika Sangkapitux } \\
\text { Economics Researcher } \\
\text { Phone: } 66 \text { (2) } 5613467 \text { ext } 134 \\
\text { Email: fecocks@ @ontri.ku.ac.th }\end{array}$ \\
\hline $\begin{array}{l}\text { Nick Ardlie } \\
\text { DSS Programmer } \\
\text { Phone: } 61 \text { (2) } 62490666 \\
\text { Email: nicka@ cres.anu.edu.au }\end{array}$ & $\begin{array}{l}\text { Dr Suwanna Praneetvatakul } \\
\text { Economics Researcher } \\
\text { Phone: 66 (2) } 5613467 \text { ext } 109 \\
\text { Email: fecoswp@ @ontri.ku.ac.th }\end{array}$ \\
\hline $\begin{array}{l}\text { Dr Bill Young } \\
\text { DSS adviser } \\
\text { Phone: } 61 \text { (2) } 62465729 \\
\text { Fax: } 61262465853 \\
\text { Email: bill.young@ cbr.clw.csiro.au }\end{array}$ & $\begin{array}{l}\text { Dr Numpet Winischaikule } \\
\text { Economics Researcher } \\
\text { Phone: } 6653498014\end{array}$ \\
\hline $\begin{array}{l}\text { Susan Kelo } \\
\text { Administrator } \\
\text { Phone: } 61 \text { (2) } 62490652 \\
\text { Email: } \text { susank@cres.anu.edu.au }\end{array}$ & $\begin{array}{l}\text { Chakrit Potchanasin } \\
\text { Graduate Student, Kasetsart University } \\
\text { Khomsak Prayoonwong } \\
\text { Graduate Student, Kaestsart University } \\
\text { Sairung Saopan } \\
\text { Graduate Student, Mae Jo University } \\
\end{array}$ \\
\hline $\begin{array}{l}\text { Wendy Merritt } \\
\text { Graduate Student }\end{array}$ & \\
\hline $\begin{array}{r}\text { Dr I } \\
\text { Research Pro } \\
\text { Agricultural and Natural } \\
\text { Phone: } 6 \\
\end{array}$ & $\begin{array}{l}\text { Menz } \\
\text { ram Co-ordinator } \\
\text { esource Economics (ACIAR) } \\
262170531 \\
\end{array}$ \\
\hline
\end{tabular}




\title{
Prediction of Monthly Discharge in Ungauged Catchments Under Agricultural Land Use in the Upper Ping Basin, Northern Thailand.
}

\author{
S.Yu. Schreider ${ }^{1}$, A.J. Jakeman ${ }^{2}$, J. Gallant ${ }^{3}$ and W.S. Merritt ${ }^{2}$ \\ ${ }^{1}$ Integrated Catchment Assessment and Management (iCAM) Centre and \\ ${ }^{2}$ Centre for Resource and Environmental Studies (CRES), The Australian \\ National University, Canberra ACT 0200, Australia. \\ ${ }^{3}$ CSIRO Land and Water, GPO Box 1666, Canberra ACT 2601, Australia
}

\begin{abstract}
The present paper describes a methodology proposed for surface runoff modelling in gauged and ungauged subcatchments of Northern Thailand. Gauged catchments are modelled using calibration against measured flow data, whereas streamflow in the ungauged subcatchments is simulated by a disaggregation procedure utilising measured streamflow data from a larger gauged catchment in which the ungauged subcatchment may be nested. The disaggregation technique is based on the assumption that the streamflow contribution from each subcatchment to the total catchment yield is proportional to a ratio of the catchment's area and its average slope. The Mae Chaem catchment in the Upper Ping River basin was selected as a case study for applying the approach. The model testing performed in two subcatchments, where the modelled streamflow was compared with the measured data, showed that the first pass approach algorithm provides the accuracy of $13-17 \%$ of the relative error for the monthly time step.
\end{abstract}

Key words: Streamflow modelling, ungauged catchments, topographic index.

\section{Introduction}

Accurate water resource assessment in Northern Thailand is of crucial importance for sustainable agricultural development in this region as well as for resolving highland-downstream conflicts allegedly related to excessive water use by highland rural communities. Fair water resource allocation is especially important during the dry season because in regions with a monsoon 
climate, such as Northern Thailand, the availability of water for irrigation during that season offers a prospect of growing a second crop in one year.

The major problem of accurate streamflow modelling in Thailand as well as in any developing country is that catchments under consideration are usually very poorly instrumented. For instance, the Mae Chaem catchment at Kong Kan $\left(2157 \mathrm{~km}^{2}\right)$ has only three gauging stations: at Kong Kan (Station number 04061302), the $1268 \mathrm{~km}^{2}$ catchment of the Mae Chaem River at Huai Phung (04061201) and the $70.6 \mathrm{~km}^{2}$ Mae Mu River subcatchment at Ban Mae Mu (04061202). A map of the Mae Chaem catchment, subcatchments and station locations is presented in Figure 1.

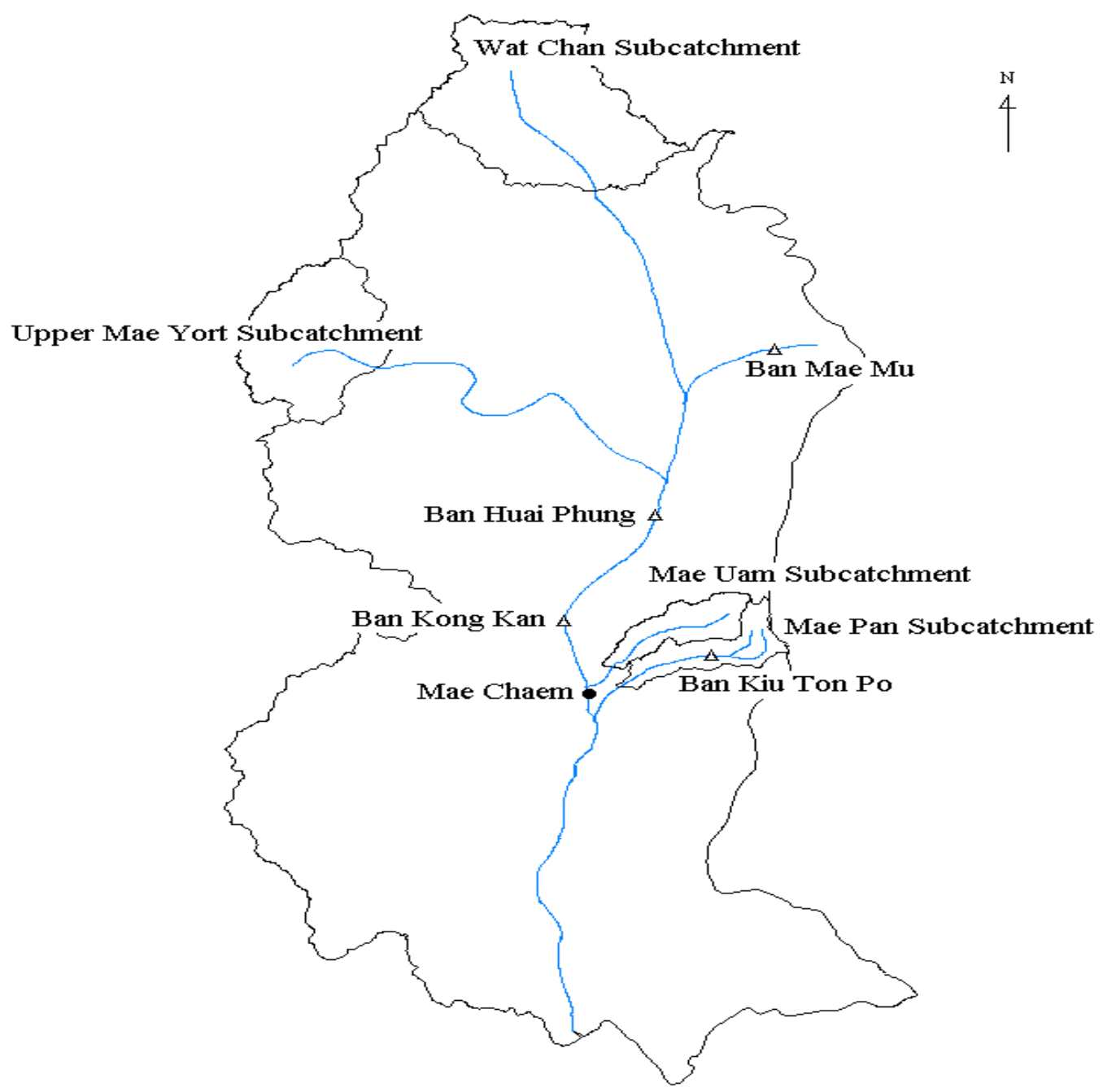

Figure 1 Map of the Mae Chaem catchment and locations of gauging stations 
The major aim of this work is to develop a method for predicting streamflow in ungauged subcatchments. The algorithm proposed below is based on a spatial redistribution of streamflow yield within a catchment according to the topographic index introduced by Beven and Kirkby [1]. The method will be tested for the gauged subcatchments of Huai Phung and Mae $\mathrm{Mu}$ by comparing the modelled and observed streamflow series. The suggested algorithm allows one to predict natural streamflow for each point in the Mae Chaem catchment if terrain characteristics above this point are available. The regulated flow for each village in the area could then be calculated as the difference between natural flow and irrigation diversion above this village.

The proposed streamflow modelling algorithm will be applied to predict surface runoff in several subcatchments of the Mae Chaem catchment within the framework of the Integrated Water Resource Assessment and Management (IWRAM) project. Objectives and general methodology of the IWRAM project are described in more detail in [5]. This project is developing a Decision Support System for management of water resources in rural catchments of Northern Thailand. Four highland subcatchments of the Mae Chaem catchment (Mae Pan, Mae Yort, Mae Uam and Wat Chan) and an area in the vicinity of Mae Chaem town were selected as case studies (see Figure 1). All these subcatchments are ungauged except Mae Pan where the quality of recorded streamflow is very poor and doesn't allow one to use it in the present work.

\section{Methodology}

The proposed surface runoff modelling algorithm has two major steps. Firstly, a rainfall-runoff model is calibrated at the catchment outlet against the streamflow recorded at the Kong Kan station. Secondly, the modelled streamflow is calculated at each point within this catchment by disaggregation of the streamflow discharge at the catchment outlet using topographic index weighting.

The first step implies an application of some model allowing one to compute the streamflow using the climatic (precipitation and temperature) input. The criterion for the model parameter optimisation is a best fit of predicted discharge to the measured values. The IHACRES rainfall-runoff model in 
conjunction with an irrigation consumption module can be used for this purpose. In a predominantly agricultural catchment, such as Mae Chaem at Kong Kan, the only major source of water consumption is irrigation supply, which can be calculated using information on areas under different crops and the irrigation consumption data for these crops per unit area. At the catchment outlet, natural flow can be calculated as a sum of measured discharge and irrigation diversion:

$$
F(k)=Q(k)+D(k)
$$

where $F(k)$ is natural (unregulated) streamflow, $Q(k)$ is a measured streamflow (regulated discharge) and $D(k)$ is irrigation diversion at the $k$-th time step. The IHACRES model will be calibrated against the natural flow values $F(k)$.

The second step is based on the approach genetically related to one proposed [1,2 and 8] for the TOPMODEL hydrological model. This approach invokes the assumption that the contribution of each part of a catchment to the total water yield is proportional to the topographic index. It allows one to predict the natural flow $f(k)$ for each part of a catchment using just a terrain characteristic of this area within the catchment considered. Therefore, if crop irrigation data for the selected subcatchment are available, the simulated regulated discharge $q(k)$ at its outlet can be expressed as a difference between natural flow $f(k)$ and irrigation diversion $d(k)$ :

$$
q(k)=f(k)-d(k)
$$

Thus the irrigation diversion module will be used for model calibration at the outlet of the gauged catchments (1). It will also be employed for restoring natural flow using the recorded discharge and the total diverted amount of water, and for the simulation of discharge in the ungauged catchments, where the regulated streamflow will be calculated as a difference between modelled natural flow and diversions as in (2).

The major components of the methodology proposed can be outlined as follows:

Modelling of irrigation consumption and restoration of the natural (unregulated) streamflow in the gauged catchment, 
Modelling of the natural flow in the gauged catchment using the IHACRES rainfall-runoff model,

Modelling of natural streamflow in ungauged subcatchments of this catchment using the streamflow disaggregation procedure. The regulated streamflow values can be computed in these subcatchments using the irrigation consumption module, and

Testing the model performance in smaller gauged catchments.

\section{Irrigation consumption module}

A water consumption module is constructed for river discharge prediction in subcatchments with considerable agricultural activities and, therefore, a significant artificial component in streamflow regime. It is based on the assumption that water consumption is defined solely by irrigation use. Thus, water consumption is calculated as a sum of products of areas under each irrigated crop and the irrigation consumption of each crop per unit of area.

Let $N$ be the number of crop types cultivated in the catchment. One plant species grown in wet and dry seasons is considered as two different types of crops. Let $v_{n}{ }^{m}$ be the irrigation consumption for crop $n \quad(n=1,2, \ldots, N)$ for time step $m$ (monthly irrigation consumption data are available, hence $m=1,2, \ldots, 12$ ) and $A_{n}{ }^{i}$ be area under the $n$-th crop in the $i$-th year. The yearly differences in $A_{n}{ }^{i}$ values reflect the changes in agricultural practice and can represent future crop/land use development in this area. Therefore, monthly water diversion for the $m$-th month in year number $i$ can be calculated as

$$
d_{m}^{i}=r \sum_{n=1}^{N} \mathrm{v}_{n}^{m} A_{n}^{i}
$$

where $r$ is a unit correction constant.

The regulated flow $q(k)$ can then be calculated for each monthly time step as

$$
q(k)=f(k)-e^{-1}\left[d_{m}^{i}(k)+P+W\right]
$$

where $f(k)$ is natural streamflow (flow value without diversion) and $e$ is an irrigation efficiency coefficient. This coefficient is defined as the ratio of the amount of water used for irrigation to the amount of water diverted. The Royal 
Irrigation Department of Thailand (RID) has estimated this efficiency coefficient as 0.60 for the wet season and 0.85 for the dry season. Values $P$ and $W$ in Equation 3 characterise the amount of water lost due to deep percolation $(P)$ and for land preparation in irrigated paddies $(W)$. According to the RID information, deep percolation can be roughly estimated as $1 \mathrm{~mm} /$ day for wet season and 1.5 $\mathrm{mm} /$ day for dry season. Land preparation in paddy fields needs $250 \mathrm{~mm}$ for the wet and $300 \mathrm{~mm}$ for the dry season.

\section{Modelling of unregulated (natural) flow in gauged catchments}

Several modelling approaches are utilised in hydrology for predicting surface runoff in instrumented catchments. Following the model classification suggested in [11], three major model classes can be identified: empirical, physically based and conceptual. The class of conceptual models is most appropriate for this work, because of their relative simplicity and relatively low data requirements. The conceptual rainfall-runoff model IHACRES, based on the Instantaneous Unit Hydrograph technique, can be used for streamflow modelling within the methodological framework outlined in Section 2. This model was described in [3 and 4]. It is based on the concept that effective rainfall passes through two parallel reservoirs: quick and slow. In catchments with monsoonal climates quick recession predominantly occurs during the wet season whereas the slow flow component dominates during the dry season. The paper [10] justified the use of the IHACRES model in the selected region and presented the preliminary results of streamflow modelling for gauged subcatchments of the Mae Chaem catchment.

The IHACRES model has two modules. A non-linear loss module which at each time step $k$ (daily and monthly time steps are proposed in this work) transforms measured rainfall $r(k)$ into effective rainfall $u(k)$ using temperature or pan evaporation data $t(k)$. The non-linear loss module is used to account for the effect of antecedent weather conditions on the current status $s(k)$ of soil moisture and vegetation conditions, and for evapotranspiration effects. Here the effective rainfall $u(k)$ is calculated from the measured rainfall $r(k)$ and temperature $t(k)$ in the catchment area by the formulae:

$$
u(k)=r(k)(s(k)+s(k-1)) / 2
$$




$$
\begin{array}{r}
s(k)=c r(k)+\left(1-1 / \tau_{w}(t(k))\right) s(k-1) \\
\tau_{w}(t(k))=\tau_{w} \exp \left(t_{\max }(20-t(k))\right)
\end{array}
$$

The constant $c$ is calculated so that the volume of effective rainfall is equal to the total streamflow for the calibration period. Importantly, it reflects the amount of potential storage in the catchment. $\tau_{\mathrm{w}}$ and $t_{\max }$ are parameters to be optimised: $\tau_{w}$ is a time constant reflecting the rate of drying of the catchment at $20^{\circ} \mathrm{C}$ and $t_{\max }$ is a factor which modulates this rate as temperature varies.

A linear module then describes the travel of effective rainfall to streamflow $y(k)$ on the basis of a total unit hydrograph approximation. This module invokes a recursive relation at time step $k$ for modelled streamflow $y(k)$, computed as a linear combination of its past values and current and past effective rainfall. The model's conceptual structure implies that the effective rainfall is considered to travel through two parallel stores. This means that the recession of streamflow is a superposition of two exponential decay functions, one of them being responsible for quick recession (recession of high flow events) and the other for recession of the slow flow component. In other words, the modelled streamflow $y(k)$ can be represented as a superposition of quick and slow components $x_{q}(k)$ and $x_{s}(k)$ :

$$
y(k)=x_{q}(k)+x_{s}(k)
$$

where $x_{q}$ and $x_{s}$ decay in an exponential fashion according to:

$$
\begin{aligned}
& x_{q}(k)=-\alpha_{q} x_{q}(k-1)+\beta_{q} u(k) \\
& x_{s}(k)=-\alpha_{s} x_{s}(k-1)+\beta_{s} u(k)
\end{aligned}
$$

In regions with a monsoon climate, such as Northern Thailand, the constant $\alpha_{s}$ could be interpreted roughly as a rate of dry season flow recession.

\section{Streamflow disaggregation procedure}

The works [1] and [2] argue that the patterns of hydrologic response within a catchment are linked to a topographic wetness index. This topographic index $\omega_{j}$ is defined for each grid cell in the catchment considered as 


$$
\omega_{j}=\ln \left[\left(A_{j} / l_{j}\right) / \tan \left(\phi_{j}\right)\right],
$$

where $A_{j}$ is the drainage area above the grid cell with width $l_{j}$ of the contour of the grid cell and the $\phi_{j}$ value is an average slope of this grid cell. The topographic index coefficient over each subcatchment $\omega$ is computed as a mean arithmetic value of these indices calculated for each of $n$ grid cells of the subcatchment considered:

$$
\omega=\frac{1}{n} \sum_{j=1}^{n} \omega_{j} .
$$

This index is normally used for predicting spatial patterns within small catchments. Here we postulate that the relative streamflow contributions from different subcatchments within a larger catchment are proportional to the mean topographic wetness index within each subcatchment. Hence, if the modelled streamflow $F$ is known at the catchment outlet, the natural (unregulated) streamflow $f$ for each subcatchment can be computed using the assumption that $f$ is proportional to $F$ with proportionality coefficient $\omega / \Omega$, where $\omega$ is a topographic index in this subcatchment and $\Omega$ is a topographic index calculated for the entire catchment. In the methodology accepted in the present work, which employs the IHACRES model, the topographic index is used for scaling the volumetric constant $c$ of the non-linear loss module of the IHACRES model (See Equation 4 of Section 4).

\section{Tests of model calibration and simulation}

\section{A. Calibration at the gauged catchment outlet:}

The calibration procedure is implemented in two steps:

The natural (unregulated) streamflow discharge $F_{i}$ is restored for the gauged catchment (Mae Chaem at Kong Kan here) using relationship (1) from Section 2. The irrigation diversion component of the water balance is computed as stated in Section 3.

The hydrological model (IHACRES) is calibrated against the restored values of natural flow. 


\section{B. Simulation for ungauged subcatchments:}

The simulation procedure can be outlined for simulating natural and regulated flow in subcatchments:

For each selected site in the catchment the natural streamflow is calculated by disaggregating the natural flow of the entire catchment according to the topographic index weighting.

The actual amount of water (regulated discharge) in this site is calculated according to Equation 2 from Section 2, using the data on areas under different irrigated crops and irrigation consumption for each crop taken into account in the irrigation consumption module from Section 3.

\section{Model testing:}

Two different ways to test the model were implemented. These are:

Streamflow data for the catchment outlet (Mae Chaem at Kong Kan) are simulated for a period other than one when the model was calibrated. It means the model is run with the same values of parameters, which were established during the calibration, in order to predict streamflow outside the calibration period.

The second test is a comparison of the simulated flow series obtained through the disaggregation procedure with the measured flow values available in some subcatchments (these are Mae Mu and Huai Phung in the case of the Mae Chaem catchment).

\section{Disaggregation}

The 'first pass approach' developed here is based on the major assumption that a topographic index in the catchments of interest can be computed using the lumped terrain characteristics of these catchments without calculating these characteristics for a set of grid cells constituting this subcatchment. This approach was employed despite some concerns about the spatial resolution at which the TOPMODEL disaggregation method can be sensibly applied, as expressed in [8]. The match of the modelled monthly values to the observed discharge was selected as an ultimate criterion to test the applicability of the 
suggested methodology. The precision of the modelling results will be evaluated using the testing procedures described in Section 6. Note that the "ungauged" catchments selected here (Huai Phung and Mae $\mathrm{Mu}$ ) are actually gauged so that the approach can be tested.

The disaggregation by topographic index is applied to the volumetric coefficient $c$ in the non-linear loss module of the IHACRES model:

$$
C \frac{a}{\tan (\phi)}=c \frac{A}{\tan (\Phi)}
$$

Here $c$ is a value of this volumetric coefficient for the non-linear module employed for simulating streamflow in the subcatchment, $a$ is the area of this subcatchment and $\phi$ is its mean slope. $A, C$ and $\Phi$ are the values of these parameters for the entire catchment (Kong Kan is used here). We chose to avoid the logarithmic transformation used in the original TOPMODEL wetness index as this element of the index arose from an assumption of exponential decline of soil transmissivity with depth, which was considered inappropriate for this scale of application.

\section{Irrigation diversion}

Two significant simplifications applied in the present work are:

- dry season irrigated crops are grown only on the furrow irrigated paddy fields, which means an ignorance of sprinkler irrigation of upland fields, and

- the data provided by the Royal Irrigation Department (RID) on long term average values for irrigation demands, calculated for the central part of Thailand, are relevant for the Mae Chaem area located in Northern Thailand.

If a monthly time step is selected for modelling then natural flow can be calculated using monthly consumption data provided by some agricultural institutions. When a daily time step is selected some additional assumptions are needed, for instance an assumption that irrigation diversion is uniform during each day of the month. 
Land use data in the Mae Chaem catchment are available in GIS format for three time slices: in 1985, 1990 and 1995 [7]. These data allow one to calculate areas under rice paddies and upland fields. In the sense of irrigation water use, the only functional information obtained from this GIS data is the area under paddy fields because no particular crops growing on these paddies are specified.

The irrigation consumption data for all type of crops, obtained from the RID, can be found in [10]. Table 1 presents a simplified version of these data, where the consumption values are rounded to $50 \mathrm{~mm}$. Onion, garlic, soybean, tobacco, barley, melon, groundnuts, cabbage and other vegetables, having similar irrigation demands, are treated as one class of cash crops (cc).

Table 1 Average monthly irrigation water demand (in $\mathbf{m m}$ ) used in the irrigation consumption module

\begin{tabular}{|l|l|l|l|l|l|l|l|l|l|l|l|l|}
\hline Month & Jan & Feb & Mar & Apr & May & Jun & Jul & Aug & Sep & Oct & Nov & Dec \\
\hline $\begin{array}{l}\text { Wet } \\
\text { season } \\
\text { rice (wr) }\end{array}$ & 0 & 0 & 0 & 0 & $250^{*}$ & 300 & 350 & 150 & 50 & 50 & 0 & 0 \\
\hline $\begin{array}{l}\text { Dry } \\
\text { season } \\
\text { rice (dr) }\end{array}$ & 250 & 200 & 200 & 0 & 0 & 0 & 0 & 0 & 0 & 0 & $300^{*}$ & 500 \\
\hline $\begin{array}{l}\text { Cash } \\
\text { crops } \\
\text { (cc) }\end{array}$ & 150 & 150 & 100 & 0 & 0 & 0 & 0 & 0 & 0 & 0 & $300^{*}$ & 100 \\
\hline
\end{tabular}

*water requirement for paddy preparation

The monthly irrigation diversion in month $i$ for the 'first pass approach' in the selected year can be calculated in the wet season as (see Section 3):

$$
d_{i}=\lambda w r_{i} S p \quad(i=J u n, J u l y, \ldots, O c t),
$$

where $\lambda(0 \leq \lambda \leq 1)$ is a proportion of total paddy area $(S p)$ covered by wet rice with irrigation demand $\left(w r_{i}\right)$ as shown in Table 1. During the dry season monthly irrigation diversion is calculated as:

$$
d_{i}=\left(\mu_{1} d r_{i}+\mu_{2} c c_{i}\right) S p \quad(i=N o v, D e c, \ldots, M a r),
$$


where, $\mu_{1}$ and $\mu_{2}\left(0 \leq \mu_{1}+\mu_{2} \leq 1\right)$, are the proportions of the total paddy area $(S p)$ covered by dry season rice, with monthly irrigation demand $d r_{i}$, and cash crops, with monthly irrigation demand $c c_{i}$, respectively.

The GIS data required for application of this streamflow modelling algorithm are summarised in Table 2. Despite the total irrigated area in the Mae Chaem catchment reaching only one percent of total catchment size, the irrigation consumption in the catchment can be very significant. The water requirement for irrigation for two possible land use scenarios in 1995 are illustrated in Figure 2. The 'maximum consumption' scenario corresponds to rice growing on $100 \%$ of paddy area during both the wet and dry seasons $\left(\lambda=1, \mu_{1}=1\right.$ and $\mu_{2}=0$ ). The 'medium consumption' scenario represents rice grown on $50 \%$ of paddy areas during the wet season and cash crops grown on $50 \%$ of paddy areas during the dry season $\left(\lambda=0.5, \mu_{1}=0\right.$ and $\left.\mu_{2}=0.5\right)$.

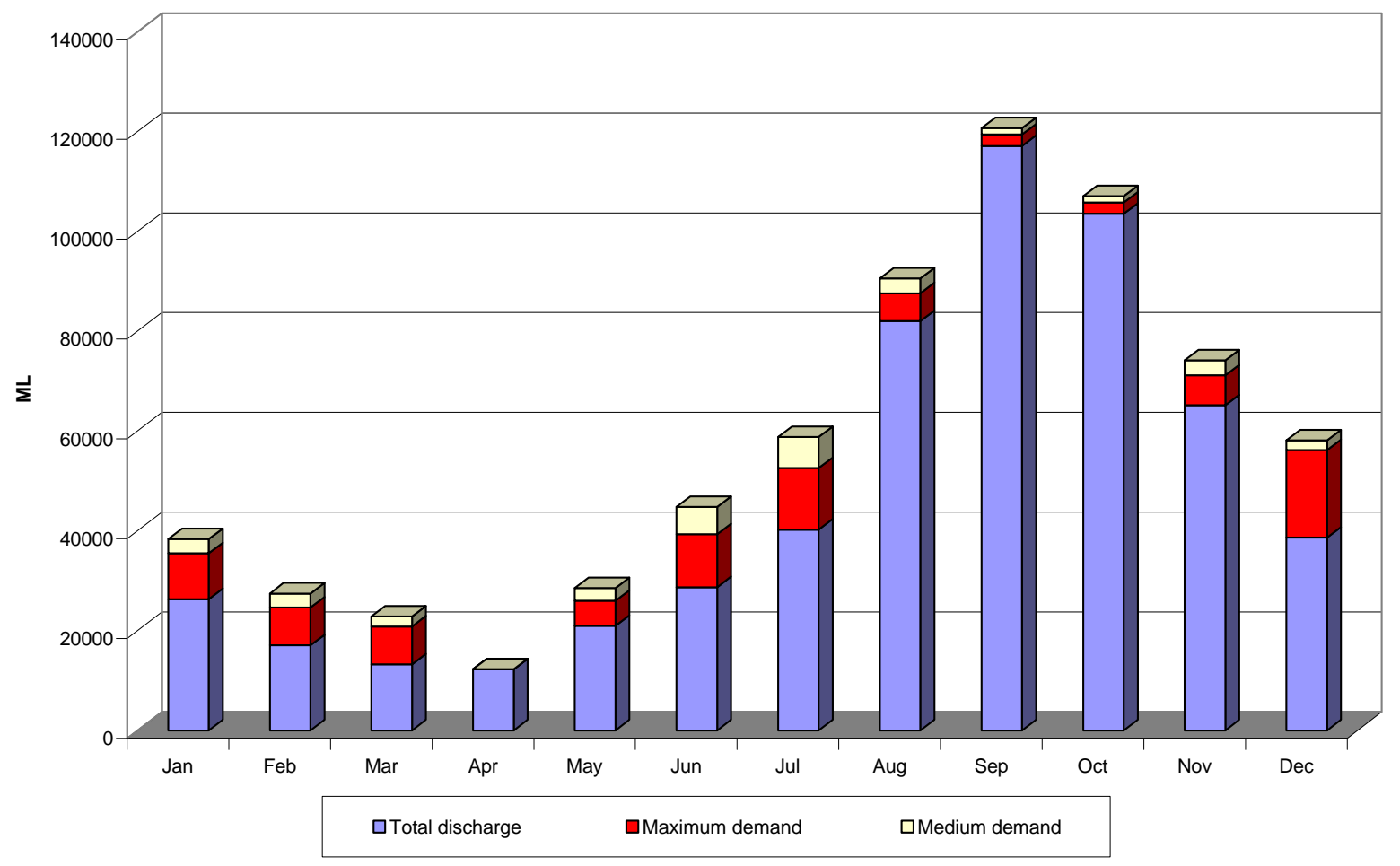

Figure 2 Mean monthly discharge in the Mae Chaem catchment at the Kong Kan station and plausible irrigation diversions for two land use scenarios in 1995 
Table 2 The characteristics of subcatchments used in the streamflow modelling

\begin{tabular}{|l|l|l|l|l|l|}
\hline Subcatchment & \multirow{2}{*}{$\begin{array}{l}\text { Area } \\
\left(\mathrm{km}^{2}\right)\end{array}$} & \multirow{2}{*}{$\begin{array}{l}\text { Mean } \\
\text { slope }\left(^{\mathrm{o}}\right)\end{array}$} & \multicolumn{3}{|l|}{ Total area under irrigation $\left(\mathrm{km}^{2}\right)$} \\
\cline { 4 - 6 } & & 1985 & 1990 & 1995 \\
\hline $\begin{array}{l}\text { Mae Chaem at } \\
\text { Kong Kan }\end{array}$ & 2157 & 19.0 & 11.8 & 18.6 & 20.1 \\
\hline $\begin{array}{l}\text { Mae Chaem at } \\
\text { Huai Phung }\end{array}$ & 1180 & 18.5 & 8.3 & 12.5 & 13.5 \\
\hline $\begin{array}{l}\text { Mae Mu at Mae } \\
\text { Mu }\end{array}$ & 68.5 & 14.3 & 0.04 & 0.10 & 0.10 \\
\hline
\end{tabular}

\section{Calibration and testing}

The model calibration was performed for five one-year periods. The parameters of the 1994 year model were selected for model simulation in the Kong Kan catchment over the whole period when streamflow data were available (test of Type 1). Model tests of Type 2 were performed for two gauged sites in the Mae Chaem catchment: Mae Mu and Huai Phung. The results of model simulation performed with and without the irrigation consumption module were compared. The simulations of natural streamflow (simulation of Type 1) were performed for four nodes of the Mae Uam subcatchment. The calibration was implemented on a daily basis, whereas model simulation results were aggregated to the monthly time step.

\subsection{Calibration of whole catchment}

The results of model calibration for the Kong Kan catchment are presented in Table 3. Table 2 shows that the areas under paddy fields remain similar in the 1990-95 period. The calibration was implemented for five one year periods in 1990-94; period 1995 was not considered as temperature data were not available in this year. Table 3 illustrates the calibration results for these four calibration periods. The quality of the model calibration was estimated using the Nash - Sutcliffe [6] efficiency $R^{2}$ and bias (mean daily error). Figure 3 illustrates graphically the model calibration for 1994. The model parameters optimised for this calibration period were used for model testing. 


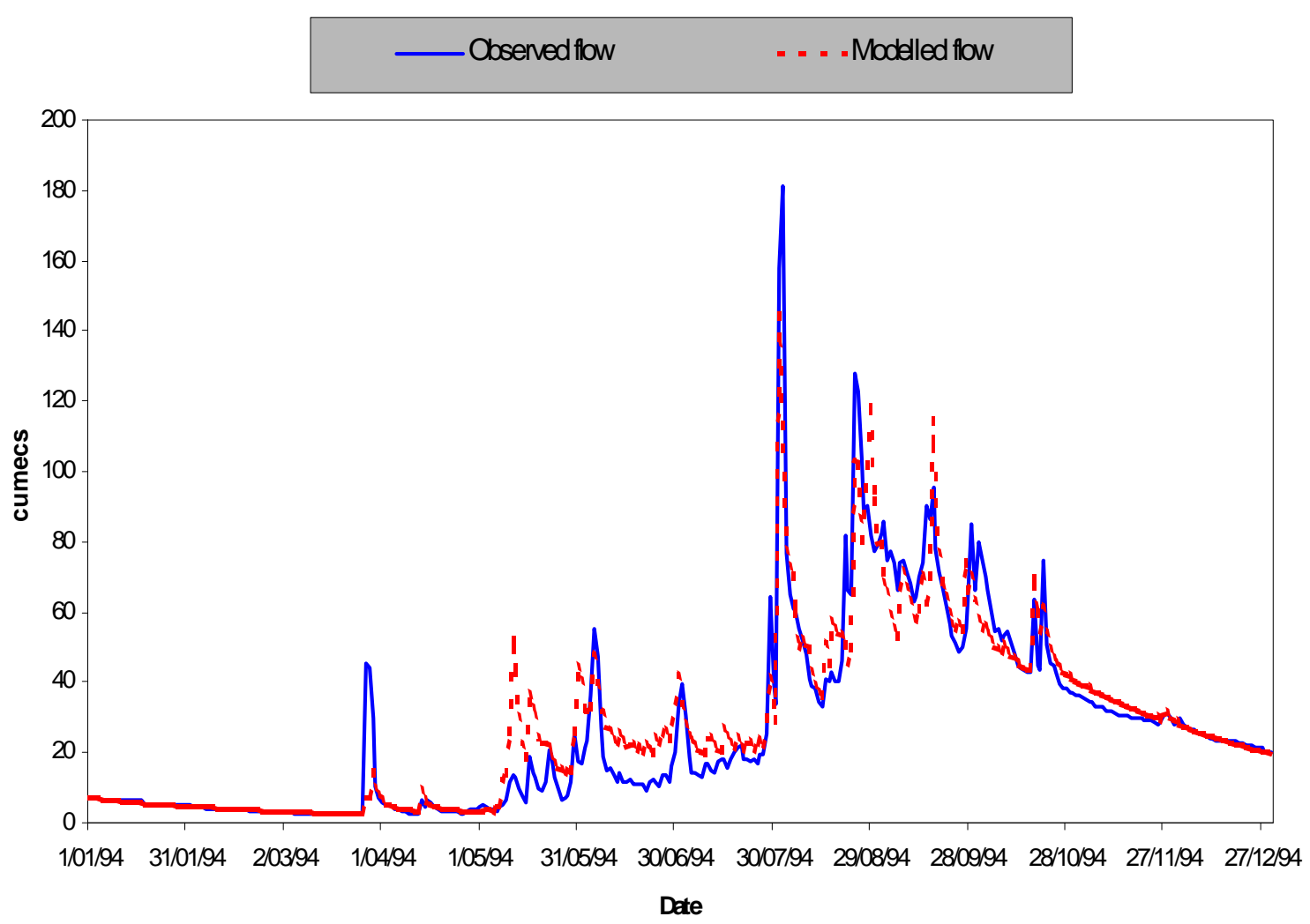

Figure 3 Calibration results for the Mae Chaem catchment at Kong Kan ('medium' irrigation diversion scenario)

Table 3 Calibration results for the Mae Chaem catchment at Kong Kan for 'no irrigation' and 'medium irrigation' diversion scenarios

\begin{tabular}{|l|l|l|l|l|}
\hline \multirow{2}{*}{$\begin{array}{l}\text { Year } \\
\text { calibration }\end{array}$} & \multicolumn{2}{|l|}{ No irrigation diversion } & \multicolumn{2}{l|}{ Medium irrigation diversion } \\
\cline { 2 - 5 } & $R^{2}$ & $\begin{array}{l}\text { Bias } \\
\text { (cumecs) }\end{array}$ & $R^{2}$ & $\begin{array}{l}\text { Bias } \\
\text { (cumecs) }\end{array}$ \\
\hline 1990 & 0.655 & -2.32 & 0.680 & -2.05 \\
\hline 1991 & 0.763 & -0.14 & 0.759 & 0.03 \\
\hline 1992 & 0.609 & -1.43 & 0.614 & -0.71 \\
\hline 1993 & 0.619 & -1.73 & 0.675 & -1.46 \\
\hline 1994 & 0.877 & -1.31 & 0.882 & -1.13 \\
\hline
\end{tabular}

Results of the monthly modelling were estimated using the mean monthly absolute and mean relative errors. 
Monthly streamflow values for the model calibration in 1994 for the "no irrigation' and 'medium irrigation' scenarios were calculated. The mean monthly absolute errors for these scenarios are $9500 \mathrm{ML} / \mathrm{month}$ and 8600 $\mathrm{ML} / \mathrm{month}$, respectively, whereas the values for mean relative errors are $24 \%$ and $23 \%$.

\subsection{Testing of whole-catchment calibration}

The model parameters calibrated in 1994 were used for modelling streamflow for the six-year period of 1989-94 when the areas under irrigated crops, hence the water consumption for irrigation, can be assumed to remain reasonably constant (see Table 2). Percent of explained variance (Nash-Sutcliffe statistics) is 0.73 calculated on a monthly basis for the 'no irrigation' diversion scenario and 0.74 for the 'medium irrigation' diversion case. Mean relative error reaches values of $30 \%$ and $22 \%$, respectively. Mean monthly absolute error, calculated for these model tests, is $10300 \mathrm{ML} / \mathrm{month}$ ('no irrigation' diversion) and $8800 \mathrm{ML} / \mathrm{month}$ ('medium irrigation' diversion). The mean annual relative errors are low, at $8 \%$ and $5 \%$ for these scenarios, respectively. This model test for medium irrigation diversion is illustrated in Figure 4.

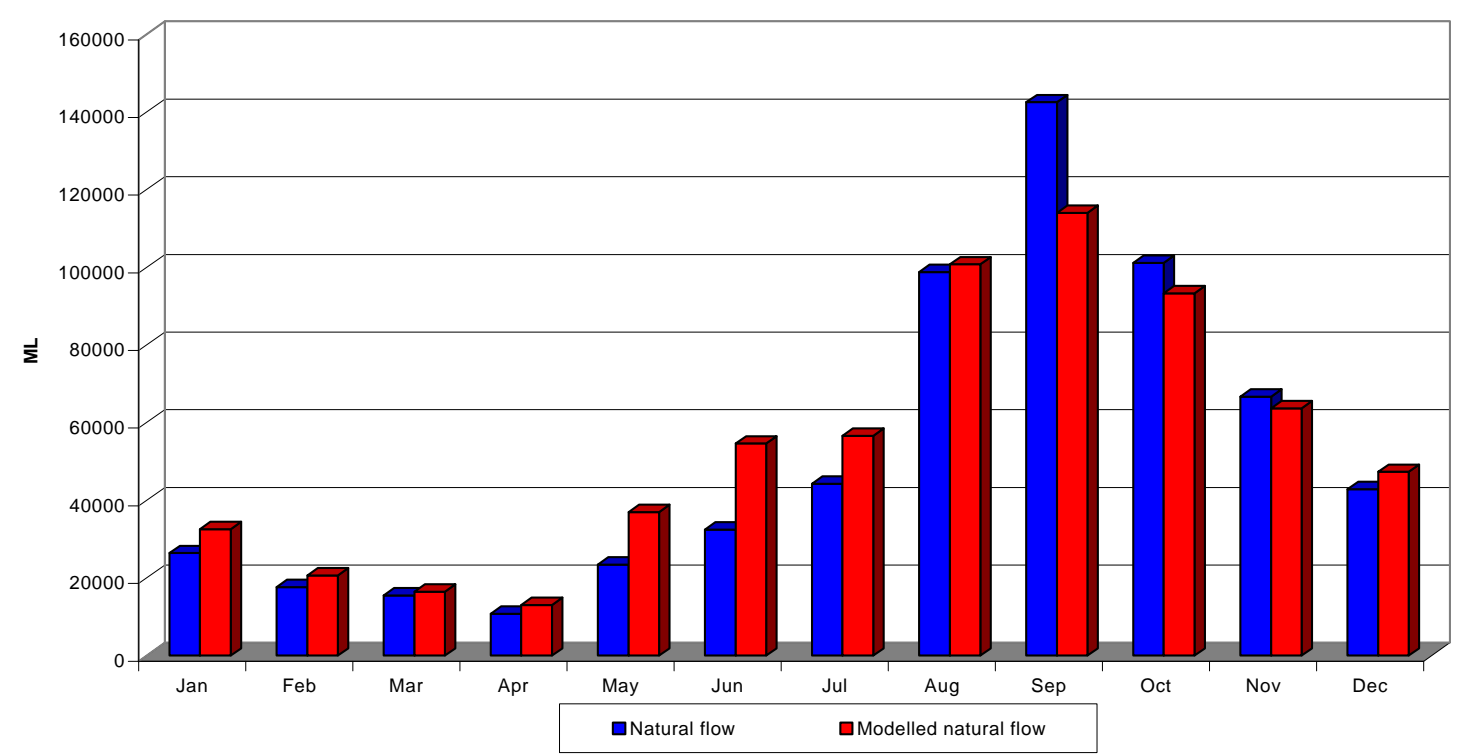

Figure 4 Model testing results for the Mae Chaem in Kong Kan. The model is applied for the period 1989-94 for the 'medium' irrigation diversion 


\section{Disaggregation results}

The streamflow disaggregation procedure was employed for streamflow modelling in two instrumented subcatchments: Mae Mu and Huai Phung. This test was also implemented for the 'no irrigation' and 'medium irrigation' cases. The mean relative errors and monthly residuals for this model test are summarised in Table 4. Figures 5 and 6 show the mean monthly observed and modelled discharge for the Huai Phung and Mae Mu subcatchments simulated using the model parameters estimated in the Kong Kan catchment for the 'medium irrigation' scenario.

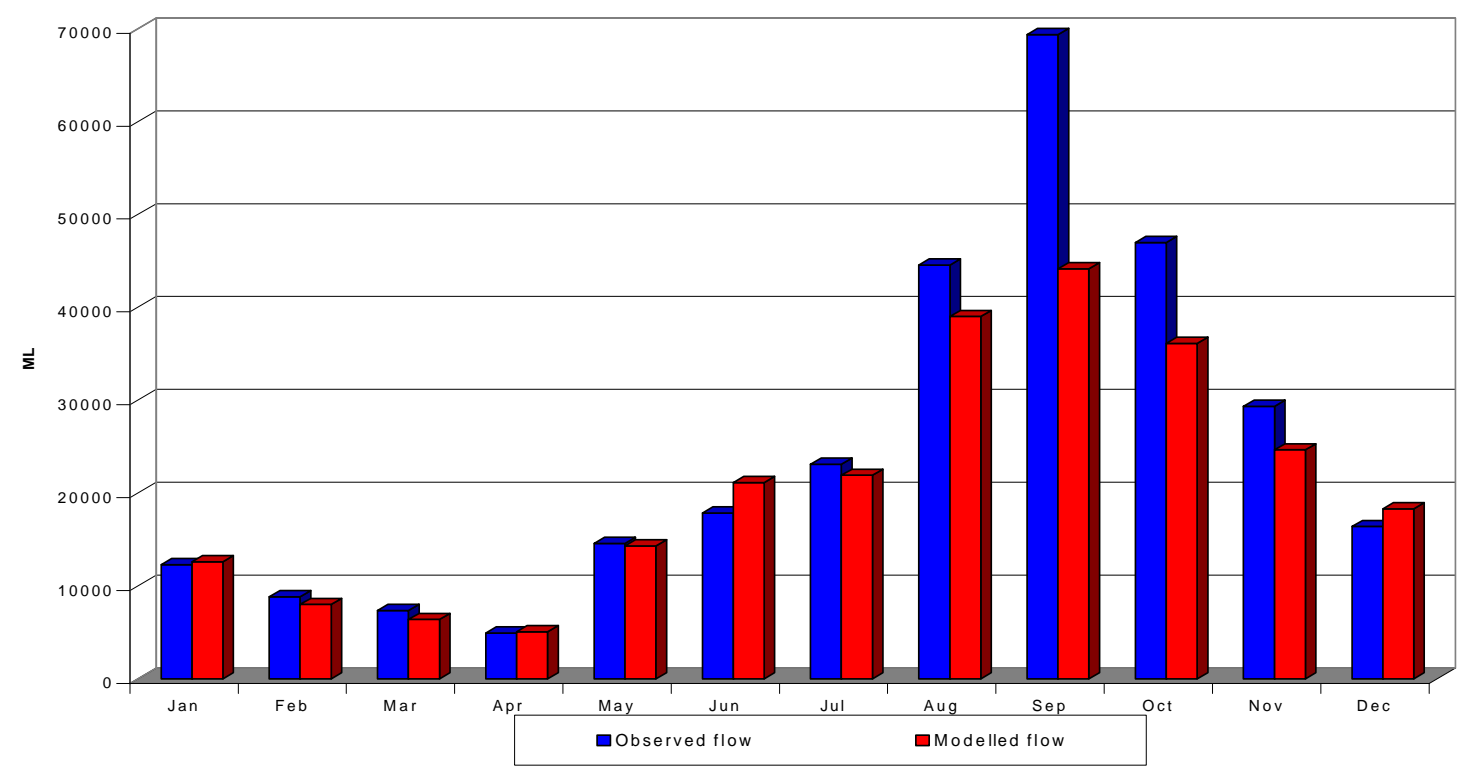

Figure 5 Results of streamflow modelling based on the disaggregation procedure for the Huai Phung subcatchment and observed average monthly discharge for the period of 1989-94 


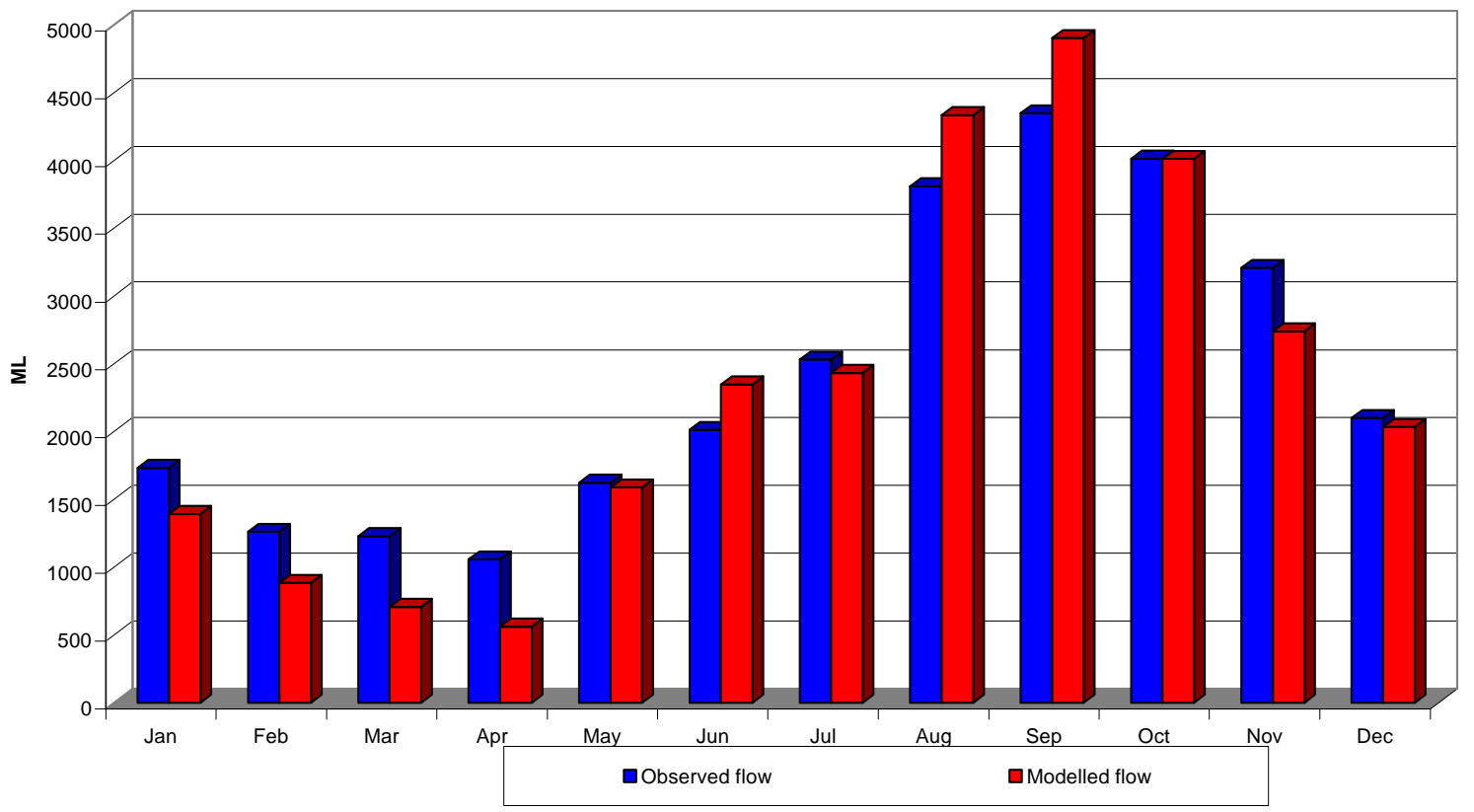

Figure 6 Results of streamflow modelling based on the disaggregation procedure for the Mae Mu subcatchment and observed average monthly discharge for the period of 1989-94

Table 4 Results of the flow disaggregation procedure using volumetric coefficient $\boldsymbol{c}$ for two subcatchments in the Mae Chaem catchment (model test 2)

\begin{tabular}{|l|l|l|l|l|}
\hline Subcatchment & $\begin{array}{l}\text { Irrigation } \\
\text { diversion } \\
\text { scenario }\end{array}$ & $\begin{array}{l}\text { Mean monthly } \\
\text { relative error } \\
(\%)\end{array}$ & $\begin{array}{l}\text { Mean annual } \\
\text { relative error } \\
(\%)\end{array}$ & $\begin{array}{l}\text { Mean monthly absolute } \\
\text { error (ML) }\end{array}$ \\
\hline $\begin{array}{l}\text { Mae Chaem at } \\
\text { Huai Phung }\end{array}$ & no irrigation & 16 & 10 & 4800 \\
\cline { 2 - 5 } & $\begin{array}{l}\text { medium } \\
\text { irrigation }\end{array}$ & 13 & 15 & 4600 \\
\hline $\begin{array}{l}\text { Mae Mu at Ban } \\
\text { Mae Mu }\end{array}$ & no irrigation & 18 & 5 & 330 \\
\cline { 2 - 5 } & $\begin{array}{l}\text { medium } \\
\text { irrigation }\end{array}$ & 17 & 3 & 320 \\
\hline
\end{tabular}

\section{Discussion and conclusions}

The methodology of surface runoff modelling in ungauged catchments suggested in the present paper has been applied and tested in the Mae Chaem catchment, Northern Thailand. The algorithm of catchment discharge disaggregation to subcatchment level is based on the assumption that the streamflow yield in each subcatchment is proportional to a topographic index 
calculated in this subcatchment. The data requirements and limitations of the proposed algorithm are discussed. The relationship between scaling issues and model precision is considered. The proposed methodology contributes to development of the general concept of regionalisation in hydrology.

The major limitation of the algorithm developed in the present work is that the scaling is restricted to non-linear module of the IHACRES model. The rates of recession of quick and slow flow components $\alpha_{q}$ and $\alpha_{s}$ (see Section 4) are quite different for different subcatchments but are assumed the same in the linear component of the IHACRES model in this work. Subcatchments in the higher part of the catchment have flatter recession rates for the dry season than catchments with lower mean elevation. The dry season streamflow in the Mae $\mathrm{Mu}$ subcatchment (Figure 6) is consistently underestimated because the recession of dry season streamflow in the Kong Kan catchment, which was scaled for modelling of the Mae Mu subcatchment, is steeper than that in the Mae $\mathrm{Mu}$ subcatchment. A possible explanation for this difference in the recession rates of dry season flow is that the catchments located in the higher areas are mist-fed during the dry season of the year. This means that during the dry season direct moisture exchange is possible between the high mountainous areas and clouds concentrating on the mountain slopes. The location of perennial swampy rainforests ${ }^{1}$ on the ridges around Mount Doi Intanon (2500 m ASL) is additional justification that such mist-fed humidity can play a significant role in the water balance in highly elevated subcatchments.

The results of the first pass approach to streamflow modelling described here are encouraging. The relative errors for monthly streamflow modelled in the "ungauged" subcatchments, estimated in the Mae Mu and Huai Phung subcatchments, fall in the interval of $13 \%-17 \%$. The algorithm allows one to predict the natural streamflow and the real discharge after irrigation diversion. The input information required for this modelling is restricted to the subcatchment area and slope for natural flow modelling and areas under different crops grown in the subcatchment for estimating the irrigation diversion.

\footnotetext{
${ }^{1}$ Results of field studies implemented in this area showed that these swamps do not dry out even during the driest months of the year.
} 
The natural question arising here is what is the difference between the algorithm described in the present paper and the simplistic idea that streamflow discharge is contributed uniformly over the catchment area. Streamflow, when modelled using the scaling of discharge according to subcatchment areas solely, fits observed flow considerably worse than the streamflow estimated by the algorithm proposed in the present paper. The ratio of areas of the Huai Phung subcatchment and the Kong Kan catchment is very close to the ratio of their topographic indices because these catchments have very similar slopes (Table 2). However, the difference in average slopes of the Mae Mu and Kong Kan catchments ( $19^{\circ}$ and $14.3^{\circ}$, respectively) makes the values of ratios of topographic indices $(0.043)$ and catchment areas $(0.032)$ quite different.

The streamflow was simulated for the Mae Mu subcatchment using the $c$ value scaled according to the catchment area for the 'medium' irrigation diversion scenario. Comparison of simulated streamflow with observed values (model test of Type 2) provided a mean monthly relative error of $33 \%$ and a mean annual relative error of $28 \%$. These results are significantly worse than those obtained using the $c$ value scaled according to the topographic index (17\% for the monthly relative error and $3 \%$ for annual relative error).

Another test was implemented in order to check an assumption that the substantial difference between observed monthly flow and modelled flow, estimated by scaling the $c$ coefficient according to the ratio of catchments' areas, is explained only by the different climatic conditions in the Mae Mu and the entire Kong Kan catchments. The mean annual rainfall calculated over the last decade in the Mae Mu subcatchment is $1200 \mathrm{~mm}$, compared with only $1000 \mathrm{~mm}$ for the Kong Kan station, which was used for the model calibration. The model was simulated for the Mae Mu subcatchment with $c$ value recalculated from $C$ calibrated in the Kong Kan catchment by formula:

$$
c=1.2 C \frac{a}{A}
$$

where $a$ is the area of the Mae Mu subcatchment and $A$ is the area of the Kong Kan catchment. The results of this test are presented in Table 5. 
Table 5 shows that the results obtained by volumetric coefficient (c) scaling according to the topographic indices are consistently better than those obtained by $c$ scaling according to the catchment areas and precipitation coefficient. The first algorithm provides better results for all months of dry season, when water supply is crucially important. For only three months (June, August and September) of wet season the discharge is modelled better using the latter case. The relative error for mean annual discharge is significantly lower for the first algorithm (3\% compared to $15 \%$ ).

Table 5 Comparative results of streamflow simulation in the Mae Mu subcatchment using the ratio of the catchment topographic indices and ratio of catchment areas multiplied to the precipitation coefficient.

\begin{tabular}{|c|c|c|c|c|c|}
\hline \multirow[t]{2}{*}{ Month } & \multirow[t]{2}{*}{$\begin{array}{l}\text { Observed } \\
\text { flow (ML) }\end{array}$} & \multicolumn{2}{|c|}{$\begin{array}{l}\text { Modelled flow using the } \\
\text { ratio of the catchment } \\
\text { topographic indices }\end{array}$} & \multicolumn{2}{|c|}{$\begin{array}{l}\text { Modelled flow using the } \\
\text { areas' ratio multiplied by } \\
\text { the precipitation coefficient } \\
1.2 \text { (ML) }\end{array}$} \\
\hline & & Flow (ML) & $\begin{array}{l}\text { Relative } \\
\text { error }(\%)\end{array}$ & Flow (ML) & $\begin{array}{l}\text { Relative } \\
\text { error (\%) }\end{array}$ \\
\hline Jan & 1732 & 1394 & 20 & 1232 & 29 \\
\hline Feb & 1261 & 885 & 30 & 782 & 38 \\
\hline Mar & 1229 & 707 & 42 & 625 & 49 \\
\hline Apr & 1058 & 561 & 47 & 496 & 53 \\
\hline May & 1622 & 1588 & 0.2 & 1403 & 13 \\
\hline Jun & 2012 & 2348 & 17 & 2075 & 3 \\
\hline Jul & 2531 & 2433 & 4 & 2150 & 15 \\
\hline Aug & 3810 & 4334 & 14 & 3830 & 0.5 \\
\hline Sep & 4348 & 4904 & 13 & 4334 & 0.3 \\
\hline Oct & 4013 & 4010 & 0.1 & 3544 & 12 \\
\hline Nov & 3208 & 2739 & 15 & 2421 & 25 \\
\hline Dec & 2101 & 2035 & 3 & 1798 & 14 \\
\hline Annual & 28925 & 27938 & 3.4 & 24689 & 15 \\
\hline
\end{tabular}


An important component of the algorithm is an irrigation consumption module developed in the present work. The results of the first pass approach demonstrate that the application of this module provides significant improvement in the modelling results for both model calibration and tests.

The approach taken here is one possible method for linking terrain attributes with the parameters of a conceptual hydrological model such as IHACRES. There is considerable scope for further research exploring and developing these relationships. If one is interested in the daily dynamics of streamflow response, then it would be worthwhile developing relationships between the non-linear response parameters of IHACRES and terrain attributes (e.g. [9]). If interest is solely on monthly volume predictions, then the simple first pass approach proposed here can be assessed for its effectiveness by calibrating IHACRES at a larger scale and utilising information on slope and area for the smaller ungauged catchment and the larger catchment in which it is nested. 


\section{Bibliography}

Beven, K.J. and Kirkby, M.J. (1979) A Physically Based Variable Contributing Area Model of Basin Hydrology, Hydrological Sciences Bulletin, 24(1), 43-69.

Beven, K.J., Kirkby, M.J., Schofield, N., and Tagg, A.F. (1984) Testing a Physically-Based Flood Forecasting Model (TOPMODEL) for Three U.K. Catchments, Journal of Hydrology, 69, 119-143.

Jakeman, A.J., Littlewood, I.G., and Whitehead, P.G. (1990) Computation of the Instantaneous Unit Hydrograph and Identifiable Component Flows with Application to Two Small Upland Catchments, Journal of Hydrology, 117, 275-300.

Jakeman, A.J. and Hornberger, G.M. (1993) How Much Complexity is Warranted in a Rainfall-Runoff Model?, Water Resources Research, 29(8), 2637-2649.

Jakeman, A.J., Saowapon Chaithawat, Jintrawet Attachi, Trisophon, Karn, Evans J.P. and Wong, F. (1997) Biophysical Component of an Integrated Water Resources Assessment Project in the Upper Chao Phraya Headwaters, Northern Thailand, International Congress on Modelling and Simulation (MODSIM97), Hobart, 8-11 December 2, 687-691.

Nash, J.E. and Sutcliffe, J.V. (1970) River Flow Forecasting Through Conceptual Models. Part I - A Discussion of Principles, Journal of Hydrology, 10, 282-290.

NCR, Thailand Landuse and Land Cover Change case Study, Bangkok, National Research Council of Thailand, 1997.

Quinn P.F., Beven K.J. and Lamb R. (1995) The $\ln (\mathrm{a} / \tan \beta)$ Index: How to Calculate it and How to Use It Within the TOPOMODEL Framework, Hydrological Processes, 9, 161-182.

Post D.A. and Jakeman A.J. (1996) Relationships Between Catchment Attributes and Hydrological Response Characteristics in Small Australian Mountain Ash Catchments, Hydrological Processes, 10, 877-892.

Schreider S.Yu., Scoccimarro, M., Jakeman, A.J., Dietrich, C.R., Saowapon Chaithawat and Merritt W.S. (1999a) Hydrologic Component of a DSS for Sustainable Development of Northern Thailand Highland Catchments, MODSS 1-6 August, Brisbane, Australia.

Wheater, H.S., Jakeman A.J. and Beven K.J. (1993) Progress and Directions in Rainfall-Runoff Modelling, Chapter 5 in: Modelling Change in Environmental Systems, A.J. Jakeman, M.B. Beck. and M.J. McAleer, eds., (John Wiley and Sons, Southampton, U.K., 101-132. 


\section{ICAM WORKING PAPERS PUBLICATIONS LIST}

iCAM99/1 A Framework for Integrated Catchment Assessment in Northern Thailand M. Scoccimarro, M., Walker, A., Dietrich, C., Schreider, S. Yu, Jakeman, A.J., Ross, H.

iCAM99/2 A Resource Management Unit (RMU) Approach to Catchment Analysis in Northern Thailand Walker, A. and Scoccimarro, M.

ICAM99/3 Impacts and Implications of Farm Dams on Catchment Yield

Schreider, S.Yu., Jakeman, A.J., Letcher, R.A., Beavis, S.G., Neal, B.P., Nathan, R.J., Nandakumar, N. and Smith, W.

iCAM00/1 Participatory Development in Thailand: A Review of Some Relevant Literature Missingham, B.

iCAM00/2 Prediction of Monthly Discharge in Ungauged Catchments Under Agricultural Land Use in the Upper Ping Basin, Northern Thailand Schreider, S. Yu, Jakeman, A.J., Gallant, J and Merritt, W.S.

iCAM00/3

iCAM00/4

iCAM00/5 